\title{
RACJONALNE I EMOCJONALNE DETERMINANTY ODDZIAEYWANIA PRODUCT PLACEMENT NA KONSUMENTÓW
}

\begin{abstract}
Utrzymanie pozycji konkurencyjnej firmy na rynku wymaga poszukiwania skutecznych form komunikacji z nabywcą. Jedną z nich jest product placement, który oznacza świadomą ekspozycję produktu w filmach i programach telewizyjnych. Decyzje zakupowe konsumentów są często kształtowane pod wpływem lokowanych produktów, z którymi spotykają się w czasie oglądania filmów, seriali, programów czy lektury książek. Uwzględniając specyfikę product placement dostrzeżono dylemat czy decyzje, które są skutkiem oddziaływania tego narzędzia kształtowane są w oparciu o racjonalny wybór, czy wynikają z przesłanek emocjonalnych. Uwzględniając powyższe, za cel publikacji przyjęto przedstawienie relacji emocjonalnych i racjonalnych przesłanek decyzji zakupowych konsumentów podejmowanych pod wpływem product placement.

$\mathrm{Z}$ przeprowadzonych analiz wynika, że konsumenci w swoich decyzjach zakupowych kierują się częściej racjonalnymi argumentami. Wpływ product placement na decyzje zakupowe uzależniony jest od subiektywnej oceny wiarygodności przekazu, jaki towarzyszy temu działaniu. Jeżeli przekaz dotyczący produktu powiązany jest logicznie z treścią programu lub wsparty jest przez eksperta $\mathrm{z}$ danej dziedziny, to siła oddziaływania tego narzędzia na zakup będzie większa. Autorzy zakładają, że uwzględnianie przez klientów opinii, wiedzy i doświadczenia ekspertów jest przejawem racjonalnego zachowania, odmiennie niż w przypadku celebrytów. Potwierdzeniem racjonalnych argumentów, którymi kierują się konsumenci jest fakt, że częściej kupują produkty, które były prezentowane przez specjalistę lub eksperta, a nie aktora czy celebrytę. Przeprowadzone badania pozwalają zatem przyjąć tezę, że efekty oddziaływania product placement na decyzje zakupowe, w przeważającej części są konsekwencją racjonalnych argumentów, chociaż można w nich także dostrzec wpływ bodźców emocjonalnych.
\end{abstract}

Słowa kluczowe: decyzje zakupowe, lokowanie produktu, konsument, racjonalność decyzji zakupowych.

\footnotetext{
${ }^{1}$ Dr Kazimierz Cyran, Wydział Ekonomii, Katedra Marketingu i Przedsiębiorczości, Uniwersytet Rzeszowski; e-mail: kacyran@gmail.com

2 Dr Sławomir Dybka (autor korespondencyjny), Wydział Ekonomii, Katedra Marketingu i Przedsiębiorczości, Uniwersytet Rzeszowski; e-mail: slawekd@univ.rzeszow.pl
} 


\section{WSTĘP}

Komunikacja marketingowa współczesnych przedsiębiorstw odbywa się z wykorzystaniem wielu narzędzi. Dążące do wyróżnienia swojej oferty firmy, poszukują skutecznych metod oddziaływania na klienta, dostrzegają determinanty decyzji zakupowych o rożnym charakterze i zwracają uwagę na product placement ${ }^{3}$. Uwzględniając jego specyfikę powstaje dylemat, czy decyzje zakupowe, które są skutkiem oddziaływania tego narzędzia, kształtowane są w oparciu o racjonalny wybór czy wynikają z czynników emocjonalnych. Celem publikacji było określenie relacji emocjonalnych i racjonalnych przesłanek decyzji zakupowych podejmowanych pod wpływem product placement. W artykule wykorzystano wyniki badań własnych, podejmując próbę weryfikacji tezy, zakładającej, że decyzje zakupowe konsumentów podatnych na lokowanie produktu oparte są o przesłanki racjonalne. Źródłem prezentowanych wyników są badania własne przeprowadzone na próbie 400 respondentów, mieszkańców woj. podkarpackiego i małopolskiego. W celu doboru obiektów do badań zastosowano kwotowy dobór próby, który odzwierciedlał strukturę populacji generalnej w badanych województwach. Za statystyki kontrolne przyjęto wiek, płeć i miejsce zamieszkania z podziałem na wieś i zróżnicowane pod względem wielkości miasta. Badanie przeprowadzone zostało w IV kwartale 2016 roku oraz w I kwartale 2017 roku. Z uwagi na regionalny charakter badania nie jest zasadne uogólnianie uzyskanych wyników na całą populację.

\section{RACJONALNE I EMOCJONALNE ASPEKTY DECYZJI ZAKUPOWYCH}

W literaturze poruszane są kwestie oceny, czy konsument w swoich zachowaniach jest racjonalny, czy emocjonalny. Problem stanowi jednak fakt, że mimo trwałej obecności pojęcia ,racjonalny” w naukach społecznych, nie jest ono jednoznaczne. Termin ten odnoszony jest zazwyczaj do ludzkiej wiedzy (przekonania, style myślenia, poglądy) oraz do ludzkich działań. Stąd też można spotkać się z poglądami, że zachowania konsumenta są racjonalne, a czasem, że powinny być racjonalne. Idąc tym tokiem rozumowania można wskazać na różne kryteria racjonalności (ekonomiczne, psychologiczne, społecznoorganizacyjne, biologiczne) i ich mierniki. Ocena racjonalności zachowań jest utrudniona, gdyż to, co jednej osobie może wydawać się racjonalne, w ocenie innej osoby może już takie nie być. Podobnie trudno jednoznacznie ocenić, czy np. zakupy nieplanowane można traktować jako nieracjonalne. Na te wątpliwości odpowiada ekonomia behawioralna, która ukazuje, że konsument w gruncie rzeczy postępuje emocjonalnie, racjonalnie jedynie starając się argumentować swój wybór ${ }^{4}$.

Racjonalność zachowań konsumentów jest współcześnie dostrzegalna w trendach dotyczących konsumpcji, np. w dekonsumpcji. Wiąże się ona z świadomym i celowym ograniczeniem ilości dóbr i usług do racjonalnych poziomów z punktu widzenia jednostki. Dekonsumpcja oznacza zatem odpowiedzialność konsumentów za swoje decyzje i wybory. Powodów wzrostu znaczenia tego trendu można upatrywać w odczuwalnej dużej niepewności funkcjonowania gospodarstw domowych, odejściem od ilościowej do jakościo-

${ }^{3}$ L. Eagle, S. Dahl, Product Placement in Old and New Media: Examining the Evidence for Concern, "Journal of Business Ethics" 2018, Vol. 147, p. 611.

${ }^{4}$ M. Nalewajek, Racjonalność i irracjonalność zachowań konsumentów na rynku ustug fryzjerskich, „Konsumpcja i Rozwój” 2015, nr 10, s. 70. 
wej orientacji konsumentów względem produktów, czy wzrostu konsumpcji w sferze niematerialnej. Następuje transformacja podejścia od materialnego do emocjonalnego, gdyż konsumenci zaczynają preferować różne doznania nad samo posiadanie dóbr materialnych.

Racjonalność konsumpcji może ujawniać się w podejściu do zakupów będącego konsekwencją np. racjonalizacji w odżywianiu (rezygnacji z produktów niskiej jakości i wartości), współpracy konsumenckiej (współużytkowaniu oznaczającemu elastyczne, oszczędne wykorzystywanie produktów), czy smart shopping (umożlwiający racjonalne planowanie budżetu poprzez dążenie do zakupów w niskich cenach) $)^{5}$.

Co prawda występują trudności w sformułowaniu jednorodnego, odnoszącego się do wszystkich aspektów zachowań konsumenta, kryterium racjonalności, można zauważyć jednak, iż istotną kwestią w ocenie racjonalności jest celowość i świadomość działania. Ponadto racjonalność zachowania konsumenta uzależniona jest od preferencji konsumenta i warunków, w jakich podejmowane są decyzje. Można więc przyjąć, że działalność jednostki jest racjonalna wówczas, gdy wybór celów i środków ich realizacji opiera się na rozumowaniu oraz na przyjętym i aprobowanym przez podmiot systemie wartości ${ }^{6}$. Z drugiej strony sprzedawcy i producenci podejmują działania, które tą celowość i świadomość utrudniają lub zaburzają. Wiąże się to z reguły z wykorzystaniem bodźców emocjonalnych.

Z ekonomicznego punktu widzenia, w ekonomii głównego nurtu, celem każdego gospodarstwa domowego jest dążenie do realizacji aspiracji konsumpcyjnych w wyniku maksymalizacji oczekiwanej użyteczności z konsumpcji, przy założeniu istnienia zestawu aksjomatów wystarczających do istnienia takiej funkcji. Natomiast $\mathrm{z}$ punktu widzenia czynników pozaekonomicznych (takich jak: wielkość gospodarstwa domowego, cykl życia rodziny, osobowość, styl życia, nawyki, obyczaje, tradycje, naśladownictwo, system wartości) celem konsumentów może być dążenie do osiągnięcia poziomu konsumpcji charakterystycznego dla grup społecznych, do których aspirują ${ }^{7}$.

\section{RACJONALNE I EMOCJONALNE UWARUNKOWANIA ODDZIALYWANIA PRODUCT PLACEMENT NA KLIENTA}

Można zakładać, że konsument postępuje na rynku racjonalnie, to znaczy, że dysponując określonymi zasobami pieniężnymi, tak nimi rozporządza, aby w sposób optymalny, wedle posiadanych informacji, zaspokajać swoje potrzeby. Klient jednak nie realizuje tylko zakupów bezpośrednio wiążących się z odczuwanymi potrzebami. Pewna część zakupów jest realizowana w sposób nieplanowany, co oznacza, że dokonano ich pod wpływem bodźców. Otaczająca klientów rzeczywistość jest bardzo skomplikowana, co wykorzystują producenci, menadżerowie, a także sami sprzedawcy, poprzez różnorakie narzędzia marketingowe. Reklama, cena czy opakowanie produktu, to jedne z wielu bodź-

${ }^{5}$ G. Sobczyk, Wspótczesna konsumpcja - nowe trendy na polskim rynku, Zeszyty Naukowe WSEI, seria: Ekonomia, nr 9, 2/2014, s. 87-104.

${ }^{6}$ A. Bretyn, Globalne tendencja wspótczesnej konsumpcji a racjonalność zachowań konsumentów w Polsce, Studia Ekonomiczne. Uniwersytet Ekonomiczny w Katowicach, ,Współczesne problemy ekonomiczne: polityka państwa a proces globalizacji” 2013, nr 139, s. 70.

7 T. Zalega, Nowe trendy i makrotrendy $w$ zachowaniach konsumenckich gospodarstw domowych w XXI wieku, „Konsumpcja i Rozwój” 2013, nr 2, s. 6. 
ców, które docierają do konsumentów. Można je rozpatrywać jako składające się z prostych wymiarów np. kształtu lub koloru. Dostrzeganie tych wymiarów, a następnie dostrzeżenie różnicy w wielkościach danego wymiaru, np. różnicy między kolorem czarnym i jego odmianami zależy już od wrażliwości zmysłowej klienta. Zmysłami u człowieka w sensie zdolności rozróżniania bodźców są wzrok, dotyk, słuch a także smak i zapach. Intrygujący jest fakt, że konsument czasami, choć nie dostrzega zmiany wielkości bodźca, to reaguje na tę zmianę. Nazywa się to spostrzeganiem podprogowym ${ }^{8}$.

W tym kontekście warto zwrócić uwagę na narzędzie, którego oddziaływanie na klienta opiera się właśnie o to dostrzeganie i identyfikację produktów. Product placement to celowe i odpłatne umieszczanie w określonych przekazach produktów w funkcji rekwizytów, w celu wywołania skutku reklamowego. Taki sposób prezentacji towaru (usługi) jest skuteczny, pokonując psychologiczne bariery, jakie wytworzyła w świadomości odbiorców tradycyjna reklama Product placement jest najczęściej używany w filmach, co pozwala na uwiarygodnienie zarówno produktu, jak i świata filmu. Widz-konsument zostaje poddany działaniu dwóch bodźców - bezwarunkowemu (scena filmowa wywołująca uczucie przyjemności) i warunkowemu (scena z użyciem produktu) na zasadzie styczności. Oczekiwana reakcja warunkowa to pozytywne skojarzenia i emocje związane z produktem. Uwiarygodnieniu podlega jednak także świat filmu, trudno bowiem stworzyć dziś przestrzeń bez marek, bez znanych sieci restauracji, hoteli itd. ${ }^{9}$

Ten sposób promowania marki może być nie tylko uzupełnieniem reklamy, ale częściowym, jej zastąpieniem. Lokowanie produktu to najczęściej wizualne przedstawienie marki lub jej cech charakterystycznych w filmach, serialach czy też programach telewizyjnych, ale występować może także w książkach, grach komputerowych, teledyskach i spektaklach teatralnych. Product placement stara się kreować markę w taki sposób, aby dany produkt wyróżniał się na tle pozostałych ${ }^{10}$. Wpływa on na pamięć i postawy konsumentów, którzy z założenia nie zdają sobie często sprawy, że poprzez spontaniczne oglądanie programów telewizyjnych zapamiętują pojawiające się $\mathrm{w}$ nich marki ${ }^{11}$, że działa on na ich wybory, gdyż z półki sklepowej ludzie wybierają częściej te produkty, które gdzieś już kiedyś widzieli ${ }^{12}$.

W pewnym sensie product placement można utożsamiać z kryptoreklamą, której przypisuje się negatywne aspekty, jednak nie musi ona wprowadzać w błąd adresatów przekazu reklamowego. Do takich legalnych środków kryptoreklamy można zaliczyć właśnie rekwizyt reklamowy oraz coraz bardziej popularny blog reklamowy, który jest jednocześnie jednym z nowszych środków reklamy internetowej. Rekwizyt jest natomiast środ-

8 A. Falkowski, T. Tyszka, Psychologia zachowań konsumenckich, Gdańsk 2001, s. 16, 75-76.

9 M. Harasimowicz, K. Walotek-Ściańska, Product placement $w$ filmie, Zeszyty Naukowe WSH, Zarządzanie, 2014, nr 2, s. 269.

${ }^{10}$ K. Plata-Gardas, Product placement na gruncie nowej ustawy o radiofonii i telewizji, „Przegląd Ustawodawstwa Gospodarczego" 2011, nr 7, s. 16.

${ }^{11}$ K. Williams, A. Petrosky, E. Hernandez, R. Page, Product placement effectiveness: revisited and renewed, "Journal of Management and Marketing Research" 2011, Vol. 7, p. 5.

12 M. Strużycki, T. Heryszek, Nowoczesna reklama na wspótczesnym rynku, Warszawa, 2007, s. 126. 
kiem wykorzystywanym w ramach kilku form reklamy, np. w reklamie telewizyjnej, kinowej, internetowej, prasowej ${ }^{13}$.

Product placement zwykle usytuowany jest blisko poziomu zdolności odbioru świadomego. W głównej mierze chodzi o informacje wzrokowe. Konsument przeważnie pochłonięty przez fabułę filmu świadomie nie zauważa prezentowanych produktów. Niektórzy uważają, że już sam product placement jest typem zbliżonym do reklamy podprogowej, argumentując to tak, że głównym kontekstem jest film a nie reklama w nim się znajdująca. Uwaga widza skupiana jest na akcji, a każde pojawienie się marki w jej tle jest uważane za przejaw podświadomy. I chociaż product placement nie należy do przekazów niewidocznych, to faktycznie często prezentowany jest w taki sposób, że jego odbiór jest tylko częściowy. Product placement należy jednak rozpatrywać bardziej pod kątem odbioru podświadomego niż podprogowego ${ }^{14}$.

Odwołując się do sytuacji bodźcowej warto również wyjaśnić, czym jest spostrzeganie. Jest to proces informacyjny, odbywający się na poziomie zmysłów człowieka. Za pomocą tego procesu konsument jest świadomy określonych cech reklamowanych produktów. Posiadana przez konsumenta wiedza na temat określonego produktu to efekt uczenia się. Natomiast cechy, wiedza, dotyczące spostrzeganego przedmiotu lub jego reklamy mogą być modyfikowane przez emocje, które są odpowiedzialne za nadanie im właściwego sensu z punktu widzenia oceny użyteczności. Rezultatem jest motywacja zakupu przejawiająca się potrzebą posiadania. Jak można zauważyć, procesy te można porównać do ciągu przyczynowo-skutkowego, gdzie każdy z nich oddziałuje na siebie.

W procesie tworzenia reklamy istotny jest sposób wyrażania emocji - ekspresja. Emocje określane są zwykle przez psychologów jako specyficzne procesy regulacji, uruchamiane, gdy człowiek styka się z sytuacjami (bodźcami) mającymi znaczenie dla organizmu lub osobowości ${ }^{15}$. Sygnały nadawane przez reklamy wzbudzają różne uczucia od radości lub obojętności, aż po strach i wstręt. Wynika z tego, że reklamy mogą przekazywać zarówno pozytywne, jak i negatywne emocje. Odwołując się do pozytywnych emocji pozytywnie nastawiają potencjalnego klienta do prezentowanego produktu (poprzez humor, przyjazną muzykę, uśmiech). Reklamy mogą także kojarzyć się negatywnymi emocjami, wówczas negatywne emocje, mają nakłonić konsumentów do zakupu wywołując np. lęk spowodowany nie stosowaniem prezentowanego produktu ${ }^{16}$.

Jedną z ważniejszych cech odróżniających wpływ product placement na konsumentów, od pozostałych form promocji jest to, że zdecydowana większość nośników rozrywki, w jakie wkomponowane są marki (np. film, serial, książka) ma charakter narracyjny, który łączy się z tzw. reakcją uczestnictwa, czyli przeniesieniem odbiorcy w świat narra$\mathrm{cji}^{17}$. Na reakcję tę składają się z kolei dwa zjawiska - identyfikacja i projekcja. Identyfikacja polega na tym, że widzowie nośników podzielają uczucia bohaterów, a jednocześnie

${ }^{13}$ S. Kaczmarczyk, Podstawowa klasyfikacja komunikacji marketingowej, Zeszyty Naukowe Uniwersytetu Szczecińskiego, nr 866, „Problemy Zarządzania, Finansów i Marketingu”, 39/2015, s. 38.

${ }^{14}$ V. Salvador, J. Mas, Hollywood marki. Product placement $w$ kinie amerykańskim, Warszawa 2010, s. 123-130.

15 A. Jachnis, J.F. Terelak, Psychologia konsumenta i reklamy, Bydgoszcz 2000, s. 121.

16 A. Falkowski, T. Tyszka, Psychologia zachowań konsumenckich, Gdańsk 2001, s. 16, 75-76.

17 A. Choliński, Product Placement; planowanie, kreacja i pomiar skuteczności, Warszawa 2013, s. $228-230$. 
rzutują własne emocje na oglądane postaci. Projekcja natomiast to emocje konsumentów, które rzutują na scenerię ${ }^{18}$. Inną obok reakcji uczestnictwa reakcją konsumentów są metody heurystyczne. Polegają one na twórczym rozwiazywaniu problemów tam, gdzie inne metody nie są w stanie w schematyczny sposób ich rozwiązać ${ }^{19}$. Z punktu widzenia product placement kluczowa jest heurystyka dostępności. Częste pokazywanie danej marki w nośnikach rozrywki może wywołać u widzów wrażenie, że jest ona najczęściej nabywana. Powoduje to wzmocnienie wartości tej marki. Z kolei efekt ekspozycji sugeruje, że wystarczające jest ukazanie marki w tle, by wytworzyć u konsumenta uczucie zaznajomienia. Ekspozycja danego bodźca dowodzi więc, że bodziec ten preferowany jest nawet wtedy, gdy jednostka nie jest tego świadoma, że go widziała. Drugoplanowa ekspozycja marki czasami może być znacznie lepiej odebrana przez konsumentów, niż jej bezpośrednie ukazanie. Pokazuje to, że nie tylko silne wyeksponowanie marki, ale także subtelne przedstawienie product placement może skutecznie wpłynąć na konsumentów ${ }^{20}$.

W kontekście powyższych rozważań warto dostrzec występowanie kilku formatów product placement:

1. Miejsca „zobacz i czuj”: są to identyfikatory marki reklamodawcy (np. logo, kolory) włączone do scenerii programu, w kolorystyce marki, co rezonuje ze stylem i uczuciami, które marka chce przekazać (np. modne, zaawansowane technologicznie). Ten format składa się wyłącznie z wizualnych identyfikatorów marki.

2. Rekwizyty: rzeczywiste markowe produkty są w tym przypadku wyraźnie prezentowane w różnych przypadkach podczas programu, bez aktywnej interakcji człowiek - produkt.

3. Interaktywne lokowanie: ta forma pociąga za sobą interakcję między markowym produktem i osobą (postać, prezenter, zawodnik). Interakcja może być wizualna (np. kucharz dodający markowy składnik do dania) lub słuchowa (np. wspominając markę jako nagrodę za konkurs). Ten model wymaga większego powiązania z fabułą, jednocześnie najsilniej oddziałuje na klientów, mimo iż zaangażowanie i ekspozycja marki jest największa, ta silna ekspozycja marki jest neutralizowana poprzez jej zasadne wykorzystanie $\mathrm{w}$ fabule programu ${ }^{21}$.

Lokowanie produktu lub marki jest jednym z najszybciej rozwijających się segmentów w branży reklamowej, a marketerzy są coraz bardziej zainteresowani określeniem możliwych rynków zbytu dla tej techniki reklamowej. Dotyczy to w szczególności telewizji, w której marki wbudowane, są obecnie równie ważne i eksponowane jak tradycyjne reklamy. Konsumenci łatwo odróżniają reklamy od programów publicystycznych i zazwyczaj unikają lub ignorują tradycyjne przekazy marketingowe. Ponadto z większym prawdopodobieństwem rozpoznają strategiczny charakter tradycyjnych reklam, podczas

\footnotetext{
${ }^{18}$ A. Helman, J. Ostaszewski, Historia myśli filmowej, Gdańsk, 2007, s. 52-53, 147-150.

19 J. Stobiecka, Modele pomiaru jakości marketingowej produktów, Kraków 2010, s. 84.

20 A. Choliński, Product Placement..., s. 228-230.

${ }^{21}$ N. Dens, P. De Pelsmacker, A. Leonids, How to mix brand placements in television programmes to maximize effectiveness, "International Journal of Market Research" 2016, Vol. 58, issue 5, p. 651.
} 
gdy oglądając treści publicystyczne czy rozrywkowe, mogą być nieświadomi perswazyjnej intencji osadzonych treści stanowiących tło ${ }^{22}$.

\section{ODDZIALYWANIE PRODUCT PLACEMENT NA DECYZJE ZAKUPOWE KONSUMENTÓW W KONTEKŚCIE ICH RACJONALNOŚCI (W ŚWIETLE BADAŃ WŁASNYCH)}

Lokowanie produktu to jedno z wielu działań mających służyć kształtowaniu decyzji zakupowych. U podstaw tych działań leży chęć wskazania na cechy produktów w sytuacjach, które nie są bezpośrednio kojarzone z reklamą, tj. bezpośrednim, natarczywym namawianiem do zakupu. Zjawisko product placement jest działaniem, które ma na celu wywołać określone reakcje konsumentów w sposób podświadomy. Jeżeli przyjmie się takie założenie, należy podkreślić, że samo oddziaływanie będzie tym skuteczniejsze im mniejsza będzie świadomość konsumentów w zakresie działań i intencji, jakie tym działaniom towarzyszą. Chcąc ocenić świadomość konsumentów w zakresie badanego zjawiska i jego wpływ na decyzje zakupowe zapytano respondentów o product placement i jego wpływ na decyzje zakupowe (wykres 1).

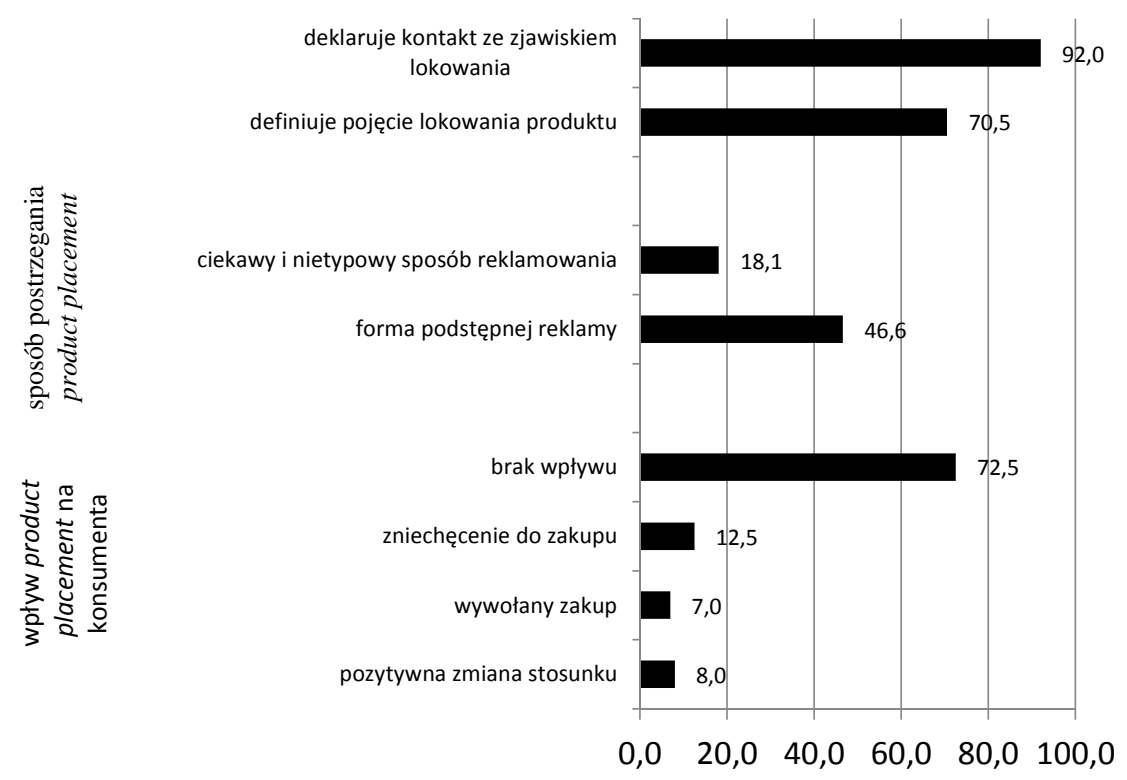

Wykres 1. Znajomość zjawiska product placement i jego wpływ na decyzje zakupowe (\%)

$\mathrm{Z}$ danych zawartych na wykresie 1 wynika, że zjawisko lokowania produktu jest powszechnie znane. Ponad $70 \%$ badanych potrafi zdefiniować te działania, a na kontakt

22 J. Matthes, B. Naderer, Product placement disclosures: Exploring the moderating effect of placement frequency on brand responses via persuasion knowledge, "International Journal of Advertising" 2016, Vol. 35, No. 2, p. 185. 
z produktami lokowanymi wskazało ponad $90 \%$ pytanych. Niestety, jak wynika z badań, omawiane działania cechuje niska skuteczność oddziaływania na decyzje zakupowe. Zaledwie $15 \%$ respondentów wskazało, że product placement jest działaniem, które wywołuje pozytywne reakcje przejawiające się pozytywną zmianą wizerunku (7\% badanych), czy wywołaniem reakcji zakupowej - co zadeklarowało 8\% respondentów. Spośród wszystkich respondentów, 12,5\% przyznało, że natarczywość w prezentowaniu produktu w trakcie filmów, czy innych programów powoduje u nich zniechęcenie do zakupu. Dla zdecydowanej większości badanych $(72,5 \%)$, obecność produktów w różnego rodzaju programach i połączone $\mathrm{z}$ tym akcentowanie ich cech, nie wywiera żądnego wpływu na decyzje zakupowe. $Z$ opinii respondentów wynika, że są oni świadomi zjawiska lokowania produktu i odczytują je jako działania marketingowe kojarzone z reklamą, których zadaniem jest wpłynąć na ich decyzje zakupowe. Najwięcej pytanych (47\%) wskazało, że pod omawianym pojęciem kryje się podstępna reklama, która ma zachęcić klienta do zakupu. Niespełna 1/5 respondentów zaznaczyła, że lokowanie produktu w ciekawy i nietypowy sposób reklamuje produkty.

Dla decyzji związanych z lokowaniem produktu kluczową staje się kwestia wyboru miejsca prezentacji produktu, co warunkuje skuteczność przekazu i wydatkowanych na ten cel środków. Wyniki badań wskazują na zróżnicowanie, jakie występuje w zakresie spostrzegania product placement w wybranych kanałach komunikacji (wykres 2).

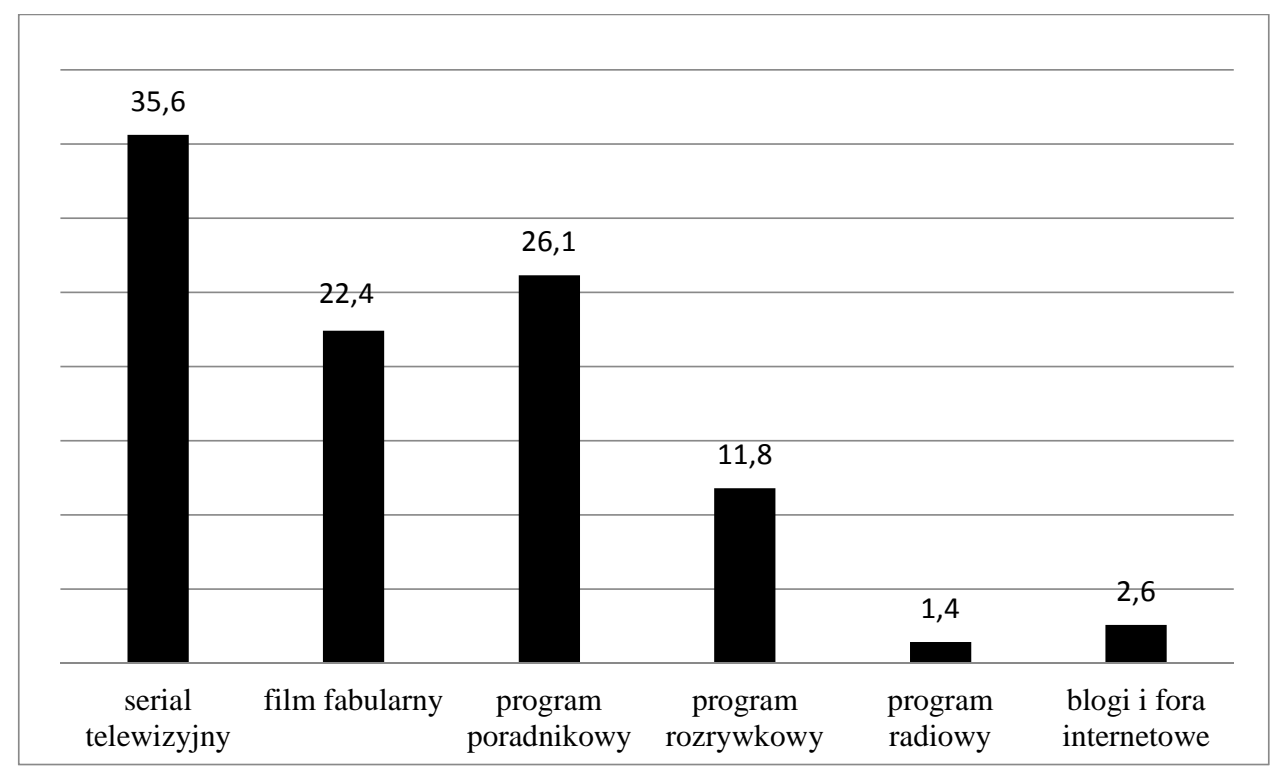

Wykres 2. Najczęściej wskazywane przez respondentów miejsca lokowania produktów (\%)

Z przeprowadzonych badań wynika, że respondenci w wielu miejscach dostrzegają lokowanie produktu. Najwięcej pytanych, jako główne źródło tego typu reklamy wskazuje serial telewizyjny. Kolejnym źródłem badanych przekazów są programy telewizyjne o charakterze poradnikowym (doradczym), gdzie w trakcie programu wykorzystywane są 
poszczególne produkty opatrzone atrybutami umożliwiającymi identyfikację marki i nazwy produktu. Trzecim w kolejności źródłem informacji o produktach były firmy fabularne, a w dalszej kolejności programy rozrywkowe. Najmniej respondentów jako miejsce, w którym zauważyli lokowanie produktów wskazało programy radiowe oraz blogi i fora internetowe.

Przedstawione informacje dotyczące obecności product placement wskazują na to, że tego typu działania przykuwają uwagę odbiorców, ale nie dają odpowiedzi na pytanie o skuteczność tych działań mierzoną decyzjami zakupowymi konsumentów. W celu zbadania omawianego wpływu, w kolejnych pytaniach poproszono o oszacowanie wiarygodności przekazów kierowanych do konsumentów za pośrednictwem product placement oraz wpływu badanej reklamy na decyzje nabywcze (wykres 3). Respondenci do dyspozycji mieli sześciostopniową skalę 0-5, gdzie 0 oznacza brak wiarygodności/znaczenia, 5 bardzo duża wiarygodność/znaczenie.

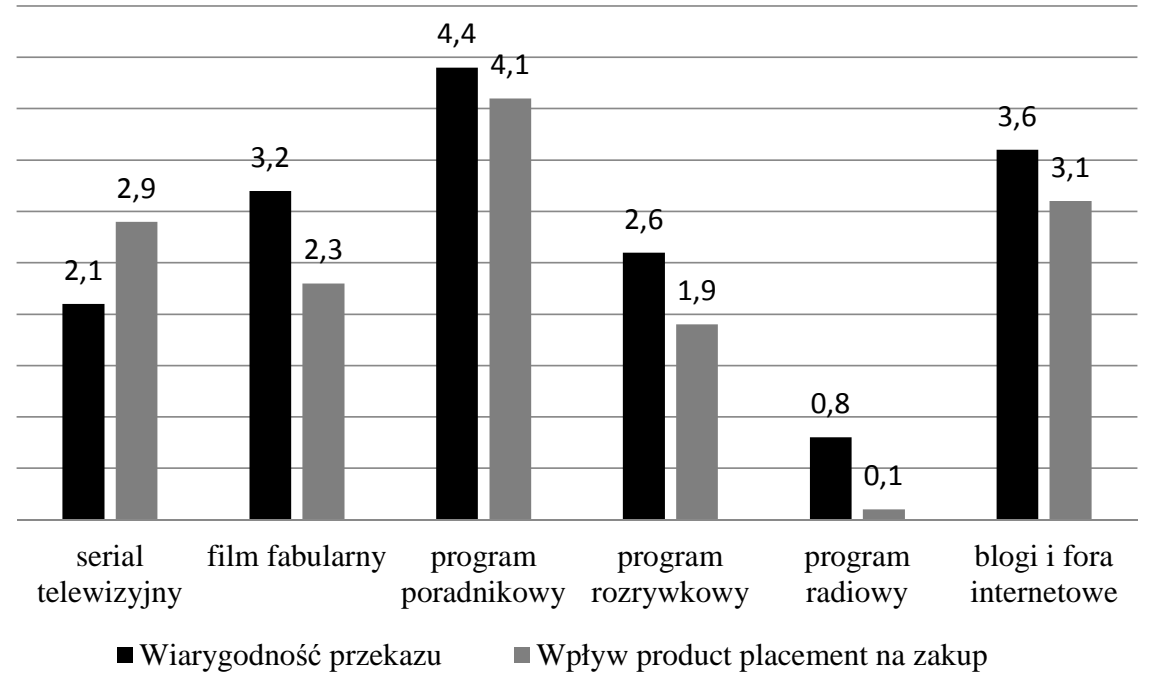

Legenda: 0 - nie ma żadnego znaczenia, 1 - ma bardzo małe znaczenie, 2 - ma małe znaczenie, 3 - ma średnie znaczenie, 4 - ma duże znaczenie, 5 - ma bardzo duże znaczenie

Wykres 3. Wpływ product placement na decyzje zakupowe konsumentów

Respondenci w badaniu wskazali na duże zróżnicowanie zarówno wiarygodności przekazu kierowanego wybranymi kanałami, jak również różny wpływ badanych działań na zakup produktów. Największą wiarygodnością odznaczały się treści towarzyszące programom poradnikowym, w których zazwyczaj uznani eksperci wykorzystują produkty, wskazując przy tym na ich nazwę, logotyp czy opakowanie. Doświadczenie eksperta i jego znajomość staje się w tym przypadku czynnikiem sprawczym decyzji zakupowych. $\mathrm{Na}$ drugim miejscu pod względem wiarygodności plasuje się product placement prezentowany na forach dyskusyjnych i blogach internetowych. Wysokiej wiarygodności towarzyszy deklarowany duży wpływ omawianych działań na zakup produktu. Kolejne miej- 
sca $\mathrm{w}$ rankingu wiarygodności zajmują komunikaty zawarte w filmach fabularnych, programach rozrywkowych i serialach telewizyjnych. Z prezentowanych danych wynika, że wskazywana wiarygodność przekazów jest czynnikiem sprawczym zbliżonego, chociaż nieco niższego wpływu product placement na zakup. Wyjątek stanowi przykład serialu telewizyjnego, który niesie za sobą mało wiarygodny komunikat, a jednocześnie w dużym stopniu przekaz ten wpływa na zakup. O ile racjonalne wydają się decyzje, w których wiarygodny przekaz decyduje o wpływie na decyzje konsumentów, o tyle w ostatnim przykładzie za główne uwarunkowanie decyzji można przyjąć czynniki emocjonalne. Przyczyną niskiej wiarygodności lokowania produktów w trakcie seriali jest wszechobecność product placement i duża natarczywość jego oddziaływania. Dodatkowo aktorzy (celebryci) używający produktów w serialach są mało wiarygodni, jeżeli chodzi o kompetencje wyboru i polecania poszczególnych produktów. Uwzględniając przytoczone argumenty, które w racjonalny sposób wyjaśniają zjawisko niskiej wiarygodności product placement $\mathrm{w}$ serialach, warto zastanowić się, z czego wynika duży wpływ tych działań na decyzje zakupowe. Prawdopodobny powód tego zjawiska wynika z emocjonalnych uwarunkowań podejmowania decyzji, co nie musi oznaczać, że w opinii konsumenta np. podążanie za trendami w modzie i zwyczajami nie ma znamion decyzji racjonalnych.

Wykres 4 przedstawia najczęściej dostrzegane sposoby prezentowania product placement $\mathrm{w}$ opinii badanych.

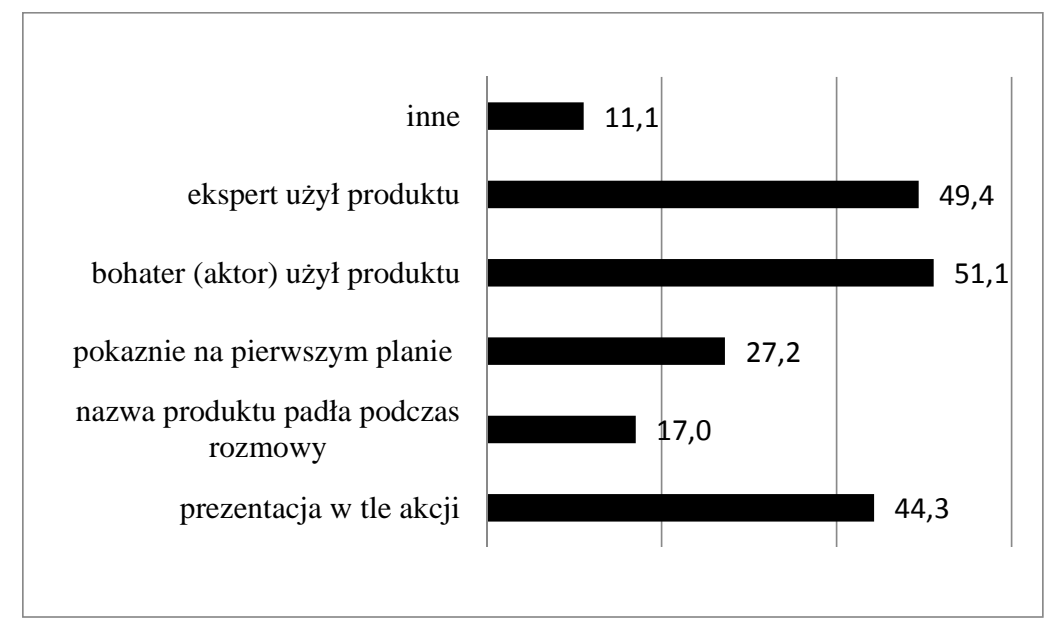

Wykres 4. Najczęściej wskazywane sposoby prezentacji lokowanego produktu (\%)

Najczęściej wskazywanym przez respondentów sposobem prezentacji lokowanych produktów było jego wykorzystanie (używanie) przez bohatera - aktora. Podobna grupa badanych $(45 \%)$ wskazała na identyfikację product placement $\mathrm{w}$ trakcie wykorzystania danego produktu przez eksperta będącego specjalistą w danej dziedzinie. Ponad 40\% pytanych przyznało, że produkt lokowany w programie prezentowany był na drugim planie, natomiast nie towarzyszyły mu żadne działania przykuwające uwagę odbiorcy. Około $1 / 4$ respondentów wskazała natomiast, że zauważony przez nich product placement prezentowany był przynajmniej przez chwilę na pierwszym planie programu. Najrzadziej wska- 
zywanym sposobem prezentacji lokowanego produktu była sytuacja, w której podczas programu wymieniona została jego nazwa lub marka. Jeżeli przyjmiemy założenie, że najskuteczniejszym sposobem lokowania produktu jest powiązanie z osobami, wokół których rozgrywa się akcja w programie, to można przypuszczać, że bohaterowie programów nie tylko ułatwiają identyfikację produktów, ale przyczyniają się do decyzji dotyczących ich zakupu. W kolejnym pytaniu respondenci wskazywali, czy zdarzyło się im kupić produkt, ponieważ używał go lubiany przez nich aktor czy ekspert? Wyniki uzyskanych odpowiedzi prezentuje wykres 5 .

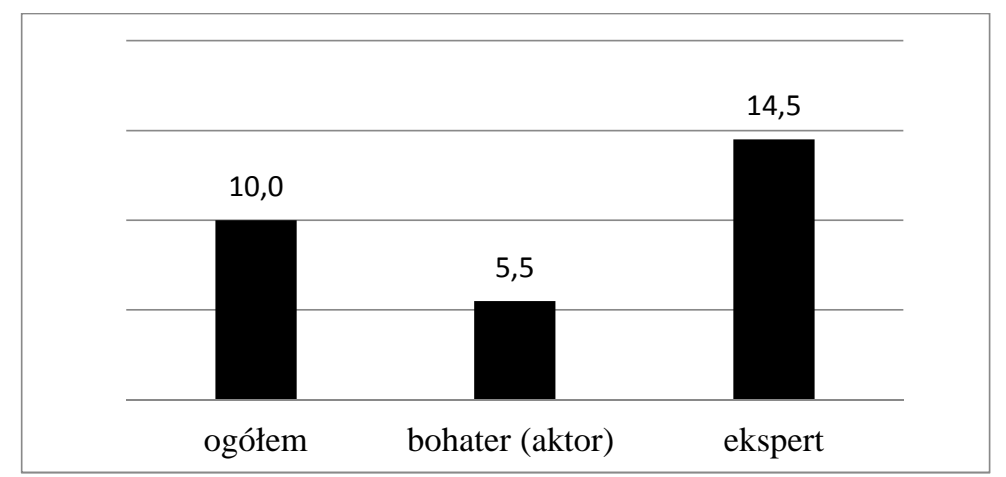

Wykres 5. Deklarowany zakup produktów pod wpływem prezentacji dokonanej przez eksperta lub celebrytę (\%)

Z przeprowadzonej analizy wynika, że zaledwie co dziesiąty badany przyznał, iż zdarzyło się mu nabyć produkt, który kojarzy się mu z aktorem lub innym uczestnikiem programu. Z analizy wynika również, że większe oddziaływanie na zakup wywierają eksperci, którzy używają produktu w programach, niż bohaterowie, którymi są znani aktorzy i celebryci. Wynikająca z analizy prawidłowość potwierdza pośrednio tezę, że konsumenci w swoich decyzjach zakupowych, wzbudzanych przez product placement doszukują się znamion przesłanek racjonalnych, a takimi mogą być rekomendacje eksperckie. Zasadnicze powody decyzji nabywczych wynikają z wielu uwarunkowań często pozamarketingowych, a tylko niewielka część sugeruje się ukrytymi w mediach przekazami. Ponadto, jeżeli już dochodzi do zakupu pod wpływem product placement, wiarygodniejsze dla nabywcy jest wskazywanie produktu przez eksperta czy specjalistę, odczytywanego jako osobę kompetentną i znającą produkt, niż sugerowanie korzyści przez znanego aktora czy celebrytę często nieznających przeznaczenia produktu.

\section{PODSUMOWANIE}

Product placement jest narzędziem często wykorzystywanym do promowania produktów w niektórych branżach. Przeprowadzone badania wskazują na to, że działania związane z lokowaniem produktu są zauważane przez odbiorców, ale ich wpływ na decyzje zakupowe jest ograniczony. Konsumenci najczęściej traktują omawiane działania z ukrytą reklamą, która nie jest odbierana jako wiarygodne źródło informacji. Z przeprowadzonych analiz wynika, że konsumenci w swoich decyzjach zakupowych kierują się często racjo- 
nalnymi argumentami. Wpływ product placement na decyzje zakupowe uzależniony jest od subiektywnej oceny wiarygodności przekazu, jaki towarzyszy temu działaniu. Jeżeli przekaz dotyczący produktu powiązany jest logicznie z treścią programu lub wsparty jest przez eksperta z danej dziedziny, to siła oddziaływania tego narzędzia na zakup jest większa. Potwierdzeniem racjonalnych argumentów, którymi kierują się konsumenci jest fakt, że częściej deklarowali oni zakup produktu, jeżeli był on prezentowany przez specjalistę lub eksperta, a nie aktora czy celebrytę. Przeprowadzone badania nie pozwalają jednoznacznie określić złożonego podłoża decyzji zakupowych konsumentów podejmowanych pod wpływem product placement. W większym stopniu są one konsekwencją racjonalnych zachowań, chociaż można dostrzec wpływ bodźców emocjonalnych, które w wielu przypadkach mogą mieć także racjonalne uzasadnienie.

\section{Literatura}

[1] Bretyn A., Globalne tendencja wspótczesnej konsumpcji a racjonalność zachowań konsumentów w Polsce, Studia Ekonomiczne. Uniwersytet Ekonomiczny w Katowicach, „Współczesne Problemy Ekonomiczne: Polityka Państwa a Proces Globalizacji” 2013, nr 139, s. 70.

[2] Choliński A., Product Placement; Planowanie, kreacja i pomiar skuteczności, Wydawnictwo Wolters Kluwer Polska SA, Warszawa 2013, s. 228-230.

[3] Dens N., De Pelsmacker P., Leonids A., How to mix brand placements in television programmes to maximize effectiveness, "International Journal of Market Research" 2016, Vol. 58, issue 5, p. 651.

[4] Eagle L., Dahl S., Product Placement in Old and New Media: Examining the Evidence for Concern, "Journal of Business Ethics" 2018, Vol. 147, p. 611.

[5] Falkowski A., Tyszka T., Psychologia zachowań konsumenckich, Gdańskie Wydawnictwo Psychologiczne, Gdańsk 2001, s. 16, 75-76.

[6] Harasimowicz M., Walotek-Ściańska K., Product placement w filmie, Zeszyty Naukowe WSH, Zarządzanie, 2014, nr 2, 2014, s. 269.

[7] Helman A., Ostaszewski J., Historia myśli filmowej, Wydawnictwo Słowo/Obraz Terytoria, Gdańsk, 2007, s. 52-53, 147-150.

[8] Jachnis A., Terelak J.F., Psychologia konsumenta i reklamy, Oficyna Wydawnicza Branta, Bydgoszcz 2000, s. 121.

[9] Kaczmarczyk S., Podstawowa klasyfikacja komunikacji marketingowej, Zeszyty Naukowe Uniwersytetu Szczecińskiego, nr 866, „Problemy Zarządzania, Finansów i Marketingu" 2015, nr 39, s. 38.

[10] Nalewajek M., Racjonalność i irracjonalność zachowań konsumentów na rynku usług fryzjerskich, „Konsumpcja i Rozwój” 2015, nr 10, s. 70.

[11] Matthes J., Naderer B., Product placement disclosures: Exploring the moderating effect of placement frequency on brand responses via persuasion knowledge, "International Journal of Advertising” 2016, Vol. 35, No. 2, p. 185.

[12] Plata-Gardas K., Product placement na gruncie nowej ustawy o radiofonii $i$ telewizji, „Przegląd Ustawodawstwa Gospodarczego" 2011, nr 7, s. 16.

[13] Salvador V., Mas J., Hollywood marki. Product placement $w$ kinie amerykańskim, Wydawnictwo SWPS Academica, Warszawa 2010, s. 123-130.

[14] Sobczyk G., Wspótczesna konsumpcja - nowe trendy na polskim rynku, Zeszyty Naukowe WSEI, seria: Ekonomia, nr 9, 2/2014, s. 87-104. 
[15] Stobiecka J., Modele pomiaru jakości marketingowej produktów, Wydawnictwo Uniwersytetu Ekonomicznego w Krakowie, Kraków 2010, s. 84.

[16] Strużycki M., Heryszek T., Nowoczesna reklama na wspótczesnym rynku, Difin, Warszawa, 2007, s. 126.

[17] Williams K., Petrosky A., Hernandez E., Page R., Product placement effectiveness: revisited and renewed, "Journal of Management and Marketing Research" 2011, Vol. 7, p. 5.

[18] Zalega T., Nowe trendy i makrotrendy $w$ zachowaniach konsumenckich gospodarstw domowych w XXI wieku, „Konsumpcja i Rozwój” 2013, nr 2, s. 6.

\title{
RATIONAL AND EMOTIONAL DETERMINANTS OF THE PRODUCT PLACEMENT IMPACT ON CONSUMERS
}

\begin{abstract}
Maintaining a competitive position in the market requires searching for effective communication with the client. One of them is product placement, which means a conscious display of the product in movies and TV shows. Consumers are more and more often buying products under the influence of the product placement, they come into contact with while watching movies, shows, programs, or reading a book. Considering the specificity of the product placement, the dilemma rises up - whether the decisions that result from the impact of this tool are based on rational choice or they are based on emotional factors. Considering the above, the aim of the publication was to present the relations between emotional and rational premises of consumer purchase decisions taken under the influence of product placement. The analysis indicates that consumers in their purchasing decisions tend to be more rational. The impact of product placement on purchasing decisions depends on the subjective assessment of the credibility of the message that accompanies this action. If the message about a product is logically related to the content of the program or is used by an expert, then the impact of this tool on purchase will be greater. The authors assume that, considering experts opinions, knowledge and experience relate to rational behavior differently than in the case of celebrities. Confirmations of rational argument used by consumers in their decisions are more frequent purchases of products which were presented by a specialist or expert rather than an actor or celebrity. The conducted research allows to accept the thesis that the product placement impact on purchasing decisions are mostly consequence of rational arguments, although some of the emotional stimuli influences.
\end{abstract}

Keywords: purchase decisions, product placement, consumer, rationality of purchasing decisions

DOI: $10.7862 /$ rz.2017.mmr.39

Tekst złożono w redakcji: listopad 2017 r.

Przyjęto do druku: styczeń 2018 r. 
